\title{
Constitutional Legitimacy
}

Randy E. Barnett

Georgetown University Law Center, rb325@law.georgetown.edu

This paper can be downloaded free of charge from:

https://scholarship.law.georgetown.edu/facpub/43

103 Colum. L. Rev. 111-148 (2003)

This open-access article is brought to you by the Georgetown Law Library. Posted with permission of the author. Follow this and additional works at: https://scholarship.law.georgetown.edu/facpub

Part of the Constitutional Law Commons, Jurisprudence Commons, and the Law and Society Commons 


\title{
GEORGETOWN LAW Faculty Publications
}

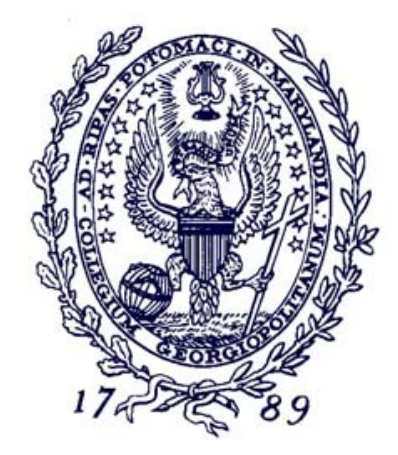

January 2010

\section{Constitutional Legitimacy}

103 Colum. L. Rev. 111-148 (2003)

\author{
Randy E. Barnett \\ Professor of Law \\ Georgetown University Law Center \\ rb325@law.georgetown.edu
}

This paper can be downloaded without charge from:

Scholarly Commons: http://scholarship.law.georgetown.edu/facpub/43/

SSRN: http://ssrn.com/abstract $=1090055$

Posted with permission of the author 


\title{
ESSAY
}

\section{CONSTITUTIONAL LEGITIMACY}

\author{
Randy E. Barnett*
}

The problem of constitutional legitimacy is to establish why anyone should obcy the command of a constitutionally-valid law. A lawmaking system is legitimate if there is a prima facie duty to obey the laws it makes. Neither "consent of the governed" nor "benefits received" justifies obedience. Rather, a prima facie duty of obedience exists either (a) if there is actual unanimous consent to the jurisdiction of the lawmaker or, in the absence of consent, (b) if laws are made by procedures which assure that they are not unjust. In the absence of unanimous consent, a written constitution should be assessed as one component of a lawmaking system. To the extent a particular constitution establishes lawmaking procedures that adequately assure the justice of enacted laws, it is legitimate even if it has not been consented to by the people. This account of constitutional legitimacy does not assume any particular theory of justice, but rather is intermediate between the concept of justice and the concept of legal validity.

\section{INTRODUCTION}

Many constitutional scholars offer their opinions about what the Constitution means. Some also have theories about how it should be interpreted-or more commonly how it should not be interpreted. But few stop to consider whether the Constitution is legitimate. This is unfortunate because if the Constitution is not legitimate, then it is not clear why we should care what it means. And if it is legitimate, we may need to know why before we can settle on how to interpret what it says.

The Constitution's legitimacy cannot, then, simply be assumed. Unless we openly confront the question of its legitimacy, we will never know whether we should obey it, improve upon it, or ignore it altogether. It is therefore extremely odd that, for all the verbiage published annually about the Constitution of the United States, one almost never hears the issue of its legitimacy addressed systematically. Perhaps this is because, for many, the Constitution is sacred and any serious treatment of its legitimacy would have to admit the possibility that it does not pass muster. It is as though we are afraid to find that there is no man behind the curtain. But another possible explanation exists as well.

* Austin B. Fletcher Professor, Boston University School of Law (rbarnett@bu.edu). I have benefited greatly from comments by Einer Elhauge, Frank Michelman, Dawn Nunziato, Larry Solum, and participants in law faculty workshops at the George Washington University, Boston University, the University of Chicago, Villanova University, the University of Notre Dame, and Harvard Law School. This Essay was also the basis of a Distinguished Lecture delivered at the George Mason University School of Law. 
Despite their silence on the issue, and whatever may be in their hearts, many constitutional scholars write as though we are not bound by the actual words of the Constitution. One way to slip these bonds is to imply that the original Constitution is illegitimate by repeating the refrain that we cannot be bound by the "dead hand of the past" or by constantly invoking the various sins of the framers. By delegitimizing the original Constitution, such rhetoric seeks to free us from its constraints. Yet it is both curious and significant that few come out and admit this.

Why not? Perhaps because they seek the obedience of the faithful and, were their delegitimation entirely successful, why on earth would anyone adhere to the commands of a law professor or philosopher or political scientist? For that matter, why adhere to the commands of the man or woman in a black robe, apart from the fact that disobedience is likely to land you behind bars in an extremely treacherous environment? By subtly undercutting the legitimacy of the Constitution while at the same time preserving its much-revered form, a constitutional scholar (or judge) can become the man behind the curtain, which perhaps is every scholar's fondest wish. Pay no attention to that bookish professor; the great and powerful Constitution has spoken!

This is a fraud on the public. Imply but do not say aloud that the Constitution is illegitimate so we need not follow what it actually says. Remake it or "interpret" it as one wills and then, because it is The Constitution we are expounding, the masses will have to follow. This strategy also allows one to adopt a stance of moral superiority towards past generations without having to assume the responsibility of proclaiming forthrightly that the document they wrote, by which the government rules, is of no authority.

In this Essay, I will ask and answer the question that others seem to fear: Why should anyone obey the commands issued by persons who claim to be authorized by the Constitution? In Part I, I examine the most commonly-held explanation for constitutional legitimacy-that legitimacy flows from the fact that "We the People" have consented to this Constitution, a view commonly referred to as the "consent of the governed" or "popular sovereignty" - and explain why it is wrong. It is wrong because it applies a standard of consent that no constitution can meet. Holding the Constitution to this unattainable ideal both undermines its legitimacy and allows others to substitute their own meaning for that of the text. This result is paradoxical since, notwithstanding the great expansion of suffrage since the nation's founding, any new and improved "interpretation" of the Constitution also will fail to be legitimated by the "consent of the governed." In Part II, I then examine and reject the principal alternative to arguments based on the "consent of the governed": that the benefits citizens receive from a constitutional order create a duty of fair play that obligates them, in return, to obey laws regardless of whether they consent to do so. 
Despite the failure of the arguments based on consent or benefits received, I maintain that laws passed pursuant to a legitimate constitutional authority can still bind us in conscience-that is, create a moral duty of obedience. In Part III, 1 begin by showing how, contrary to popular belief, unanimous consent to governance is both possible and pervasive, but also why constitutions like that of the United States could never receive the consent of "We the People." To be binding in conscience without unanimous consent, a constitution must be legitimated in some other manner. I then explain why legitimacy in the absence of unanimous consent requires putting enforceable limits on government powers-limits that would not be necessary if unanimous consent existed.

1 will contend that, if a constitution contains adequate procedures to assure that laws imposed on nonconsenting persons are just (or not unjust), it can be legitimate even if not consented to unanimously, whereas a constitution that lacks adequate procedures to ensure the justice of valid laws is illegitimate even if consented to by a majority. Indeed, only by realizing that the "consent of the governed" is a fiction can one appreciate the imperative that lawmakers respect the requirements of justice (whatever one believes those to be).

Though my thesis concerning legitimacy does depend on the claim that "justice" is independent of government fiat or whatever may happen to be commanded by positive law, it does not depend on acceptance of the particular conception of justice I defend elsewhere. ${ }^{1}$ Regardless of what conception of justice one holds, so long as one holds some conception of justice, constitutional legitimacy can be seen as a product of procedural assurances that legal commands are not unjust. The narrow thesis defended here concerns only the proper conception of constitutional legitimacy, not all the conditions that may lead to the conclusion that a particular constitutional regime is or is not legitimate. To assess the legitimacy of any given legal system would require both this procedural conception of legitimacy and a conception of justice by which to assess the adequacy of lawmaking procedures.

The procedural conception of legitimacy defended here is not reducible to a theory of justice and must be distinguished from the more familiar position commonly attributed to "natural law" theorists that an unjust law is not (in some sense) a law. ${ }^{2}$ In what follows, I do not equate

1. See generally Randy E. Barnett, The Structure of Liberty: Justice and the Rule of Law (1998) [hereinafter Barnett, Structure of Liberty] (defending a liberal conception of justice grounded in certain individual natural rights that distinguish liberty from license).

2. The actual position of natural law theorists is that an unjust law-though a positive law-does not bind in conscience. Even Thomas Aquinas was quite capable of distinguishing as a conceptual matter between those human laws that were just and those that were unjust when he declared that "[l]aws framed by man are either just or unjust." 2 Thomas Aquinas, Summa Theologica, in 20 Great Books of the Western World 233 (Fathers of the English Dominican Province trans., Encyclopaedia Britannica 1952). Rather, for Aquinas and other natural law thinkers, the issue of lawfulness is not conceptual, as it is for modern positivists, but normative. Only just laws "have the power of 
the legitimacy of a law with its propriety or "justice"-though these two concepts are closely related-nor with the mere perception that a particular law is proper or just. 1 readily concede that a validly-enacted law may be unjust even within a legitimate legal system. Nor does "legitimacy," as I am using the term, refer to whether a particular law is "valid" because it was enacted according to the accepted legal process. For example, the Constitution specifies that to be valid a law must be enacted by majorities of both houses of Congress and signed by the President.

Rather, the concept of legitimacy I will be advancing stands between the justice of laws and their validity. It looks to whether the process by which a law is determined to be valid is such as to warrant that the law is just. According to my usage, a valid law could be illegitimate and a legitimate law could be unjust. A law may be "valid" because produced in accordance with all procedures required by a particular lawmaking system, but be "illegitimate" because these procedures are inadequate to provide assurances that the law is just. Such a law would not be binding in conscience. A law might be "legitimate" because it is produced according to procedures that assure that it is just, and yet be "unjust" because in this case the procedures (which can never be perfect) have failed. Such a law would be binding in conscience unless its injustice was somehow established. ${ }^{3}$

My discussion of legitimacy will be normative and therefore also must be distinguished from more sociological or descriptive uses of the term. Many discussions of legitimacy, perhaps even most, concern whether a constitution, lawmaking process, or government is perceived to be legitimate. While a widespread perception of legitimacy may be vital to obtaining popular acquiescence to a legal regime, 1 am examining instead the conditions of legitimacy that need to exist for such a perception to be warranted.

However, one cannot appreciate the superiority of my approach, which raises questions of its own, without confronting squarely the severe and insurmountable problems with the conception of legitimacy based on the consent of the governed or "We the People." So let us now pull back the curtain and see what we find.

binding in conscience." Id. It is this issue of "binding in conscience" that informs Aquinas's endorsement of Augustine's statement that "that which is not just seems to be no law at all'; therefore the force of a law depends on the extent of its justice." Id. at 227 (emphasis added).

3. The qualification in the text follows from the fact that the duty of obedience I am discussing is a prima facie or defeasible duty. My chaim is that if you hear nothing else about a law than that it was properly enacted, this is good reason to obey in a system in which adequate justice-preserving procedures are in place and were followed. What exactly it would take to rebut this presumption in a legitimate legal system and show that the procedures have failed and have produced an unjust law is a separate and difficult question that raises important, and much discussed, questions about civil disobedience. 


\section{The Fiction of "We the People"}

The Constitution begins, "We the People of the United States ... do ordain and establish this Constitution for the United States of America."4 This was not idle rhetoric. These words were offered to claim legitimacy for the document that followed. The founders' claim of legitimacy was based, not on the divine right of kings, but on the right of "We the People" to govern themselves. They declared that "We the People" had exercised their rights and had manifested their consent to be ruled by the institutions "constituted" by this document. They made this declaration because they believed that the consent of "We the People" was necessary to establish a legitimate government and that, upon ratification, they would have gained this consent.

In this Part, I challenge the idea, sometimes referred to as "popular sovereignty," that the Constitution of the United States was or is legitimate because it was established by "We the People" or the "consent of the governed." I deny that the conditions needed to make that claim valid as to this Constitution existed at the time it was adopted or ever could exist. Though "the People" surely can be bound by their consent, this consent must be real, not fictional, and unanimous, not majoritarian. Any consent that is less than unanimous simply cannot bind nonconsenting persons. Moreover, the fiction of "We the People" can prove dangerous in practice and can nurture criticisms of the Constitution's legitimacy that are unwarranted.

\section{A. Basing the Duty to Obey the Law on Consent}

Sometimes we speak as though the Constitution itself is or is not binding on the citizenry. Yet, with one exception, ${ }^{5}$ the Constitution does not purport to bind citizens. Rather, it binds the government itself. As Rufus King, delegate from Massachusetts, stated to the Constitutional Convention: "In the establishmt [sic] of Societies the Constitution was to the Legislature what the laws were to individuals." 6 While the Constitution is law, it is law in a secondary, not a primary sense. ${ }^{7}$ It purports to bind government officials, not private individuals.

The real question, then, is not whether the Constitution is binding on citizens, but whether citizens are bound by the commands or laws issued by officials acting in its name. Does the fact that a "law" is validly enacted according to the Constitution mean that it binds one in conscience? In other words, is one morally obligated to obey any law that is

4. U.S. Const. pmbl.

5. The Thirteenth Amendment prohibits private persons, not just government, from enslaving others or holding them in involuntary servitude. U.S. Const. amend. XIII.

6. James Madison, Notes of Debates in the Federal Convention of 1787, at 231 (Ohio Univ. Press 1984) (1840).

7. See H.L.A. Hart, The Concept of Law 77-96 (1961) (distinguishing "primary rules" that direct individuals from "secondary rules" that define how the primary rules are determined). 
enacted according to constitutional procedures? Or is the only reason to obey a valid law the fear of punishment should one be caught for disobedience?

While some legal philosophers disagree, ${ }^{8}$ most citizens think that when a command is called a "law," it carries with it a moral duty of obedience-though this duty might be rebutted in particular cases. ${ }^{9}$ Certainly most lawmakers and government officials assert that citizens have a moral duty to obey properly enacted laws. When this is the common perception of "the law," and when the system that produces these legal commands lacks the requisite institutional quality-whatever it may be-to justify this favorable presumption, lawmakers in such a society will get a powerful benefit of the doubt or "halo-effect" to which they are not entitled. Therefore, if the term "law" is to carry the implication that there is a moral duty to obey, then the requisite binding quality must go in before the name "law" goes on.

A lawmaking system is legitimate, then, if it creates commands that citizens have a moral duty to obey. A constitution is legitimate if it creates this type of legal system. What quality must a constitution have to make it legitimate in this sense? Why do citizens have a duty to obey the commands of those who are designated by a constitution as lawmakers and enforcers? Most constitutional scholars avoid explicitly addressing these questions.

If pressed for an answer, many people would likely rely, at least initially, on the "consent of the governed" or what is sometimes called "popular sovereignty." 10 Characteristic is the following statement by Michael McConnell: "The people's representatives have a right to govern, so long as they do not transgress limits on their authority that are fairly traceable to the constitutional precommitments of the people themselves ...."11 Or, as George Washington said in his farewell address: "The basis of our political systems is the right of the people to make and to alter their constitutions of government... The very idea of the power and the right of

8. See, e.g., Joseph Raz, The Authority of Law 233 (1979) ("[T]here is no obligation to obey the law. ... [T] here is not even a prima facie obligation to obey it. . . [T] here is no obligation to obey the law even in a good society whose legal system is just.") (footnote omitted). 1 respond to this position at greater length in Randy E. Barnett, Getting Normative: The Role of Natural Rights in Constitutional Adjudication, 12 Const. Comment. 93, 102-05 (1995).

9. This is what philosophers like Raz call a "prima facie" obligation duty, meaning that one has a duty unless it can be shown that there is some reason why this duty does not adhere. Raz, supra note 8, at 234-35.

10. See generally Edmund S. Morgan, Inventing the People: The Rise of Popular Sovereignty in England and America (1988) (tracing development of idea of popular sovereignty).

11. Michael W. McConnell, The Inportance of Humility in Judicial Review: A Cornment on Ronald Dworkin's "Moral Reading" of the Constitution, 65 Fordham L. Rev. 1269, 1291 (1997). 
the people to establish government presupposes the duty of every individual to obey the established government."12

While Bruce Ackerman emphatically denies that legislators govern in the name of the People, ${ }^{13}$ throughout two massive works entitled "We the People," he too apparently assumes that the People can bind themselves, though he never quite comes out and says this explicitly. Instead, he speaks repeatedly of "[d]ecisions by the People," 14 "the constitutional judgement of We the People,"15 the "will of We the People,"16 "revision by the People," 17 and the People's "right to change their mind."18 In sum, for liberals like Ackerman, no less than for conservatives like McConnell, "the People" are an entity capable of making decisions, reaching judgments, having a will, and changing "their mind."19

To the contrary, in the next section, I will show that the concept of "We the People" is a fiction. I will demonstrate that constitutional legitimacy has not been conferred by either the individual or the collective consent of "We the People." As we shall see, the idea of the "consent of the governed" is not one but a series of different commonly-made arguments that must be distinguished and considered separately to see that none of them works. Though genuine consent, were it to exist, could give rise to a duty of obedience, the conditions necessary for "We the People" actually to consent to anything like the Constitution or amendments there to have never existed and could never exist. ${ }^{20}$

12. George Washington, Washington's Farewell Address (Sept. 17, 1796), reprinted in 1 Documents of American History 169, 172 (Henry Steele Commager ed., 9th ed. 1973). This passage of Washington's speech was reputedly drafted by Alexander Hamilton. See Joseph J. Ellis, Founding Brothers: The Revolutionary Generation 152 (2001).

13. 1 Bruce Ackerman, We the People: Foundations 184 (1991) [hereinafter Ackerman, Foundations] ("No small group can ever be transubstantiated into the People by virtue of legal form." (emphasis omitted)).

14. $1 \mathrm{~d}$. at 6 .

15. 1d. at 9 .

16. Id. at 10 .

17. Id. at 13 .

18. Id. at 14.

19. 1d. The very phrase "their mind" signals that something is amiss beneath the surface. If "We the People" have a single mind, should Ackerman not speak of "its mind"? He would then have to tell us what exactly the "it" is (everyone? a majority?) and how a diverse multitude of millions of people can have a single mind. If, on the other hand, there is no single mind, then should he not have said "their minds"? Yet this expression would weaken the desired imagery of a single deliberating, willing, and acting agent that (or is it "who"?) exercises judgment.

20. While Ackerman's preoccupation with the trope of "We the People" makes his work an obvious target of this critique, nowhere in his two path-breaking books does he, to my knowledge, systematically defend the normative assumption that the "will of We the People" is actually binding on any particular person, or that constitutionally-enacted laws are binding on the citizenry. lnstead, he defends his "dualist" approach as the best description of the American constitutional tradition (about which he may well be correct). See id. at 13 ("My argument ... focuses on the fact that our Constitution has never ... explicitly entrenched existing higher law against subsequent revision by the People."). 1 discuss Ackerman's dualist theory of constitutionalism below. See infra Part I.D. 


\section{B. Why "We the People" is a Fiction}

Those who justify a duty to obey the law on the basis of the "consent of the governed" must explain exactly how and when "We the People"you and I and everyone else-consented to obey the laws of the land. Some claim that by voting we consent to obey the resultant laws; others contend that residence or the failure to revolt or amend the Constitution implies consent. All of these theories collapse upon close examination. Let us consider each in turn.

1. Does Voting Constitute Consent to Obey the Law? - Because we do not live in a direct democracy in which every individual votes on every law, the most obvious answer is that we consent to obey the laws when we vote for the lawmakers who enact them. Just as a person empowers an agent to represent and bind him, when each of us votes for persons to represent us in the legislature, have we not consented to obey the laws for which they, our designated agents, vote? Perhaps. But suppose the candidate we voted for was defeated. In what way did we consent to be "represented" by his opponent, the very person we voted against? Or suppose the person we voted to be our representative votes against a particular law. In what way have we consented to be bound by a law to which we and our representative were opposed?

Well, consent does not work that way, comes the response. By choosing to vote, we have consented to the outcome of the election, whatever it may be. In a game, you consent to play by the rules even when you are losing. People often consent to a process of binding arbitration in which they know, when they consent, that they may win or lose. By the same token, when we participate in the electoral "game" or process, have we not committed ourselves to respect the outcome when our candidate loses?

But if consent is a message we communicate to others-"I consent to be bound by the outcome"-it is not clear that voting conveys such a message. Suppose some people vote, not because they consent to the outcome of an election, but in "self-defense"-that is, they vote because they hope to influence, however marginally, the result so that it is not as unfavorable to them as it might otherwise be. For example, some people might vote for the candidate who promises to support a tax cut, not because they consent to whatever the candidate might do in office, but solely because they hope to make a tax cut more likely and a tax increase less likely. They just want to keep more of their earnings. The same holds true for persons who vote for candidates who support or oppose abortion rights. To infer from their having voted for such a candidate the message that these voters consent either to the outcome of the election or to all the outcomes of the lawmaking process, whatever they may be, is to misunderstand the meaning of their voting.

Yes, but by using a vote to try to influence the outcome, has not a person chosen to participate in the process and does not this choice necessarily entail a consent to abide by the outcome? After all, should their 
candidate prevail, voters would expect those who supported the losing candidate to go along with the winning side. Unless losing voters go along with the winners, the system would fail to accomplish anyone's objectives. While this may be so, it does not follow from the fact that individual voters hope or expect others to go along if their candidate wins that they, by voting, have consented to be bound themselves. They still could be voting simply to minimize the threat to their interests posed by the lawmaking process. Voting with this motivation in no way implies consent to any outcome that may result. Therefore, the simple act of voting does not tell us whether the voter consents to the outcome of the election (and all that follows from it) or whether he or she is voting for different motives entirely.

While 1 do not agree that consent to the outcome follows from a vote cast in self-defense, suppose for the sake of argument that it does. What then do we say about the consent of those who abstain from voting altogether? They have not expressed any consent to the outcome of an election, win or lose, or to the decisions of "representatives" for whom they have neither voted for nor against. Surely, on the argument presented so far, they are not bound to obey the law by virtue of their consent.

"Not so fast," comes the reply. Provided that they were given the option of voting, those who have chosen not to participate in the election cannot complain. Consider the right of a criminal defendant to be represented in court by a lawyer. Should he waive his right to counsel and represent himself, or even stand mute, he cannot object if he is convicted-provided he was given the right to be represented. By the same token, so long as we are free to vote, if we fail to do so we cannot complain however the election comes out. After all, we had the opportunity to influence the outcome and we freely chose not to employ it.

The analogy to the right to an attorney is inapt. We do not find the defendant guilty because he consented to be so found. We find him guilty because we conclude that he is guilty. There is no reason to expect or require a defendant to consent to his prosecution. Though some defendants might, most probably do not. We do not know and we do not care because their consent does not matter. In contrast, the argument that we are bound to obey the laws because we have been given a right to vote is based on consent-the consent of the governed. 1t is not clear why, by giving someone the opportunity to consent, say by voting, one may then infer consent from a refusal to vote.

This point becomes clearer when one realizes that if consent is an expression of a willingness to go along with something, then this presupposes it is possible to express unwillingness. Just as 1 can say, " 1 consent," there also must also be a way to say, " 1 do not consent." 1 am not here talking about the likelihood of such a refusal or all the considerations that might leave one "little choice" but to consent. Rather, 1 am simply insisting that, just as the word "no" means the opposite of "yes," for consent to have any meaning, it must be possible to say "1 do not consent" 
instead of "I consent." But notice where the argument has taken us when consent to obey the laws is based on voting:

If we vote for a candidate and he wins, we have consented to the laws he votes for, but we have also consented to the laws he votes against.

If we vote against the candidate and he wins, we have consented to the laws he votes for or against.

And if we do not vote at all, we have consented to the outcome of the process, whatever it may be.

It is a queer sort of "consent" where there is no way to refuse. "Heads I win, tails you lose," is the way to describe a rigged contest. "Heads" you consent, "tails" you consent, "didn't flip the coin," guess what? You consent as well. This is simply not consent.

2. Does Residency Imply Consent? - When confronted with this argument, many might say that I have attacked a straw man. No one argues that consent is to be inferred from voting, or from having a right to vote. ${ }^{21}$ Rather, the response continues, one consents to obey the laws of the land because one has chosen to live here. Just as you are bound to obey your employer (within limits) because you consented to work at your job, you are bound to obey your landlord (within limits) because you consented to rent your apartment, and you are bound to obey the referee (within limits) when you consented to play basketball in a league, you are bound to obey the commands of government. You can always leave your job, find another apartment, or quit the basketball team, but as long as you remain you have consented to live by the authority of others and are bound to do so. By the same token, while you can emigrate from the country if you want to, so long as you choose to remain, you have tacitly consented to obey the laws of the United States. Call this the "love it or leave it" version of consent.

While it is fair to say that one really does impliedly consent to obey one's employer, a sports official, the usher in the movie theater, etc., it is not at all clear that one has consented to obey the laws of the United States simply by virtue of one's failure to emigrate. Certainly no one has ever asked me for my consent, nor you for yours. Unlike immigrants who become citizens by taking an explicit oath, those born within the boundaries of the United States are not asked or required to take an oath promising to obey the laws.

Consider for a moment the implication of such a demand. Suppose one refused to take the oath. Would one then not be bound to obey the laws of the United States? Or would one then be expelled from the country? The latter prospect presupposes that the person who is demanding we take an oath is an authority who has the right to expel us if we refuse,

21. 1 dispute this, by the way. A lot of people do argue in this manner-or at least they believe it-until the difficulties of the argument are brought to their attention. Citations cannot be provided, however, since these sorts of discussions rarely take place in print. 
but it is his authority which is at issue in the first place and which supposedly depends on our consent. All of this is quite circular.

It is always hard to explain why a circular argument is circular (without sounding circular yourself), so consider this: Suppose I come to you and demand that you sign an oath to respect my commands and you refuse. Upon your refusal I claim a right to your house and order you to leave the country. You rightly say that this is absurd. I have no authority to demand that you take an oath, so you are free to ignore me. Your refusal to take the oath would in no way obligate you to leave the country. You would be right.

Because you have not consented to my authority, I am in no position to demand that you either take an oath or leave the country. Were the present legal system to demand we take an oath, it would be making exactly the same claim. If the reason for taking an oath is to give the lawmakers authority by our consent, then unless they first have authority, they cannot demand that we take an oath. But if they already have the authority to demand we take an oath, then the oath is unnecessary to establish that authority.

That which is true for oaths is just as true for mere residence. It is equally unwarranted to base the authority of lawmakers on the so-called tacit consent of everyone who chooses to live here and does not leave the country. For remaining in this country only tacitly indicates consent if you assume that the lawmakers have the initial authority to demand your obedience or your exit in the first place. But it is their authority which is supposed to be justified on the basis of your and my tacit consent. So the problem with inferring consent from a refusal to leave the country is that it presupposes that those who demand you leave already have authority over you. Your decision to stay, therefore, cannot be the source of their authority. And their authority, if it exists, does not rest on your consent.

Lea Brilmayer has dubbed this the "bootstrapping objection."22 Brilmayer correctly identifies this as an objection to territorial jurisdictions that purport to be based on consent, not as an objection to nonterritorial jurisdictions based on actual consent:

These bootstrapping objections to contractarian formation of a government do not necessarily arise when parties create governmental entities that lack territorial status. One might, for instance, agree with another individual that in the event of a dispute both will submit to binding arbitration. Although the arbitrator's authority is established by consent, its authority is not territorial. In such cases, only the actual participants are bound; the extent of authority is not defined territorially. ${ }^{23}$

Thus, this objection will not apply to lawmaking jurisdictions based on actual unanimous consent as described in Part III.

22. Lea Brilmayer, Consent, Contract, and Territory, 74 Minn. L. Rev. 1, 12 (1989).

23. 1d. at 16 . 
Besides its circularity, there is another reason to reject the "love it or leave it" conception of consent. As I have already noted, "I consent" is a message we communicate to others. Saying the words "I consent" is fairly unambiguous (so long as there is a way to express a refusal to consent). Depending on the context, there are few, if any, other meanings we can attach to these words. Simply remaining in the country, however, is highly ambiguous. It might mean you consent to be bound by the laws enacted by Congress; or it might mean you have a good job and could not find a better one in another country; or it might mean that you speak only English; or it might mean that you do not want to leave your loved ones behind. It is simply unwarranted to conclude from the mere act of remaining in the country that one has consented to all or any of the laws thereof.

Before the Holocaust, many Jews remained in Germany when they had a chance to escape; they chose to stay for a variety of reasons. Whatever else we can say about their decision, we cannot conclude that, merely by their presence, they tacitly assented to the Nuremberg laws. I do not mean to put too much stress on this argument. There were many characteristics of the Third Reich that undermined its authority and that made it substantially different in this regard from the United States. My point is merely that, simply by remaining in the country of their birth at a time they were free to leave, German Jews cannot be said to have consented to whatever laws were enacted in that country. Neither have we. And, to return to the bootstrapping objection, the Nazis had no authority based on the consent of German Jews to put them to this choice.

3. Are We Bound by the Consent of the Founders? - Those who wish to base the duty to obey the laws on popular sovereignty or the "consent of the governed" will not give up at this point. They will then point to the fact that the government of the United States predates the birth of everyone alive today. Because it was here first, it can demand that one consent to its authority or leave the cuuntry. Recall the quote from Michael McConnell with which we began: "The people's representatives have a right to govern, so long as they do not transgress limits on their authority that are fairly traceable to the constitutional precommitments of the people themselves . . . ."24

The initial source of the authority of "the people's representatives" was not your or my consent, goes the argument, but the consent of "We the People" at the time the government was founded. It is that consent that got the government up and running legitimately, and it is that consent that empowers it to demand that you "love it or leave it." If you are born in and grow up in someone else's house, for example, you must obey the rules of the owner or move out. Your continued presence constitutes consent to the authority of the homeowner.

24. McConnell, supra note 11 , at 1291 . 
Moreover, a popular sovereignty theorist also might make the somewhat different argument that the issue of "consent of the governed" was never whether you or I consented to obey the laws by our vote or by remaining in the country. The real source of consent was the initial consent of the "We the People" to the formation of a government, and from then on, so long as the People do not successfully revolt against the government, they can be said to have tacitly consented to it. It is the failure to overthrow the government, not the refusal to leave the country, that constitutes our consent to obey its commands.

Both arguments invoke the legitimate origin of the Constitution and rest that legitimacy on the consent of "We the People" of 1789. It is this consent that gives the Constitution its initial legitimacy and which afterwards puts the onus on the citizenry to obey, leave the country, or successfully revolt. This shift in argument from our consent to the consent of "We the People" at the time of the founding now requires us to ask who exactly it was that consented to the creation of this government and what it was that gave them the power to so bind themselves and their posterity. We shall immediately see the exact same problems here as we saw with voting, only once removed. Now we are talking about deficiencies in other people's consent, not our own.

The Constitution was not approved by a unanimous vote, nor even by a majority of all persons in the country at the time. It was approved by a majority of delegates to conventions in each state. These delegates were elected by a majority of those who voted for delegates. Were the delegates who voted against the Constitution (and those who voted for these dissenting delegates) bound by their consent? And what about the majority of inhabitants who were not permitted to vote for any delegate? Though voting requirements varied with local jurisdictions, in no place could women, children, aliens, indentured servants, or slaves vote. More-. over, it was not uncommon to have a property requirement that limited the voting rights of white males and free black males. In what sense can a small minority of inhabitants presuming to call themselves "We the People" bind anyone but themselves? And assuming they could somehow bind everyone then alive, how could they bind, by their consent, their posterity? ${ }^{25}$

One response to this, already suggested above, is that the refusal to revolt or overthrow the government is what constitutes an ongoing tacit consent to obey the lawful commands of the system the founders created. But this is asking much too much of those who would refuse their consent. Does one really manifest a consent to obey the commands of someone much more powerful simply because one does not physically resist the threat of violence for noncompliance? True, physical resistance is

25. For what it is worth, in the Preamble to the Constitution, the framers do not purport to bind their posterity but rather to secure for it "the Blessings of Liberty." U.S. Const. pmbl. 
evidence of a lack of consent, but if the cost of physical resistance is high enough, we cannot conclude that a passive nonresistance equals consent.

The same is true to a lesser extent about a failure to emigrate. The cost of emigration, in terms of what one gives up by leaving, is simply too high to infer from the failure to emigrate a consent to obey the laws of the land. Moreover, the failure of enough people to band together to overthrow a government tells us nothing about the consent of the individ$u a l$ to be bound by the commands of the government, and therefore it tells us nothing about why laws are binding on individuals. To argue otherwise is to assert that the majority, by its failure to revolt, can bind the minority to obey the laws.

To this the popular sovereignty theorist might respond that, when the Constitution provides less costly mechanisms for change--such as an amendment process - it is the failure to amend the Constitution, rather than the failure to revolt successfully against the government, that manifests consent to obey all the laws. But this response is transparently inadequate. Whether a constitutional amendment requires a supermajority vote of both houses of Congress and approval by three quarters of state legislatures, or a simple majority of the electorate, the failure to obtain an amendment through this process hardly indicates consent by anyone to the existing regime. A refusal to approve a change in the Constitution implies neither that those who supported the defeated amendment nor those who opposed it consented to the existing regime. In the end, we are returned once more to the problem of inferring the consent of the minority or of the individual from the consent of the majority. Consent simply does not work that way.

We are now in a position to appreciate the fundamental reason why none of the foregoing arguments based on consent succeeds: For consent to bind a person, there must be a way to say "no" as well as "yes," and that person himself or herself must have actually consented. Unless we are speaking of children, incompetents, or principals who have actually consented to be represented by an agent, no person can literally consent for another. This fact poses an insurmountable obstacle for all theories of legitimacy that base the "consent of the governed" on anything less than unanimity. As Jeffrey Reiman has argued,

[T]here is nothing inherently legitimating about the electoral process. If anything, the electoral process is the problem, not the solution. ... [T] he policies that emerge from the electoral process will be imposed on the dissenting minority against its wishes. And then, rather than answering the question of legitimacy, this will raise the question with respect to those dissenters. Why are the exercises of power approved by the majority against the wishes of (and potentially prohibiting the desired actions of) the minority obligatory with respect to the minority? Why are 
such exercises of power not simply a matter of the majority tyrannizing the minority? 26

Arguments on behalf of constitutional legitimacy based on majoritarian rather than unanimous consent attempt the moral equivalent of squaring a circle.

4. Why Acquiescence Does Not Equal Consent. - The appeal of arguments based on tacit consent dies hard, however, and perhaps this is the reason: Can we not say that almost everyone in some sense "accepts" the current government of the United States as legitimate? Would not the number who reject its legitimacy be very small indeed? Were this not the case, would not the government be hopelessly unstable? If general acquiescence to the existing legal regime is an empirical fact, and one that is essential to its functioning existence, can the regime not also claim the tacit consent of the population and the legitimacy that flows from such consent?

Those who base tacit consent on general acquiescence have confused a "rule of recognition" with the conditions of constitutional legitimacy. A rule of recognition is the way the population can identify the existence of an operating legal regime. ${ }^{27}$ But just as knowing that a particular command is "the law" does not tell us whether it is binding in conscience, knowing that a legal regime "exists" as a result of general acquiescence does not tell us whether there is a moral duty to obey its commands.

Of course, some form of general acquiescence is necessary for any constitution to be implemented and to maintain its continued existence as positive law. As Frederick Schauer has noted, this acquiescence distinguishes the Constitution of the United States from another document entitled "The Constitution of the United States" that 1 might write and have my friends ratify. ${ }^{28}$ Ratification by plebiscite or representative con-

26. Jeffrey Reiman, The Constitution, Rights, and the Conditions of Legitimacy, in Constitutionalism: The Philosophical Dimension 127, 134 (Alan S. Rosenbaum ed., 1988). As he elaborates:

These questions not only point up the error of taking electoral accountability as an independent source of legitimacy, they also suggest that it is mistaken to think of electoral accountability and constitutional provisions as alternative sources of legitimacy. Rather, the Constitution with its provisions limiting the majority's ability to exercise power is the answer to the question of why decisions voted by a majority are binding on the minority who disagree.

Id.

27. See Hart, supra note 7, at 92-93 (stating that a rule of recognition is "a rule for conclusive identification of the primary rules of obligation"). Notice Hart's reference here to the "rules of obligation." Hart also contended that if the rule of recognition were satisfied, citizens would then not only be compelled or "obliged" to obey the law, they would also be under an "obligation" or duty to obey. Id. at 84-85. This 1 reject for reasons I have given elsewhere. See Barnett, Structure of Liberty, supra note 1, at 17-23.

28. Frederick Schauer, Precedent and the Necessary Externality of Constitutional Norms, 17 Harv. J.L. \& Pub. Pol'y 45, 52 (1994) (“[O]nly one of these 'Constitutions' would be the Constitution of the United States, because only one of these documents would 
ventions can provide an effective rule of recognition to the population and can help to attain a general acquiescence to the constitutional regime, though these procedures are far from indispensable.

However acquired, mere acquiescence-which every existing government and scheme of positive law can claim - and unanimous consent cannot be the same thing. For what is at issue here is not whether a legal system exists, but whether a particular existing constitutional regime is legitimate. Only if it is legitimate can an existing legal system issue commands to the citizenry that bind individuals in conscience. If acquiescence, which every functioning regime can claim, equaled unanimous consent, even the most oppressive regime could claim to be entitled to a duty of obedience on the basis of such "consent" so long as it managed to exist. Clearly this proves too much.

While some degree of acquiescence may be necessary to establish a command as positive law, more than acquiescence is needed to create a moral duty to obey such a command. James Madison caught a glimpse of the moral problem when he observed in $\mathbf{1 7 8 4}$ that the unratified Virginia Constitution "rests on acquiescence" only, which is a "dangerous basis." 29 Actual consent by an individual can create a moral duty, but one individual cannot consent for another, and unanimous consent, all concede, cannot and has never existed. ${ }^{30}$

There is considerable irony in the widespread claim that "tacit" consent is the source of the duty to obey the laws. Many who assert this would never accept so attenuated a notion of consent to justify, say, the lease of a television or the waiver of liability for harm. In these contexts, they demand a rarified version of "informed" consent that hardly, if ever, exists. They require "complete information" on everything one is consenting to (or giving up) and a diversity of sufficiently attractive alternative choices before concluding that someone has actually consented to an enforceable contract to buy a stereo. Unless these conditions are met, they insist that such consent is "fictitious" or "coerced." 11 Yet we are asked, often by the very same people, to accept the proposition that merely by virtue of living in the town in which we were born or by failing

have been accepted, socially and politically, by the people of the United States as their Constitution.").

29. James Madison, Notes for a Speech Favoring Revision of the Virginia Constitution of 1776, in 8 The Papers of James Madison 75, 78 (Robert A. Rutland et al. eds., 1973). Madison believed that if "ratified by" the people, the Virginia Constitution would be "more stable and secured agst. [sic] the doubts \& imputations under which it now labours." Id.

30. Though unanimous consent to something like the Constitution is impossible to obtain, I explain later in this Essay why, contrary to popular assumption, unanimous consent to other governance structures is both quite possible and quite common. See infra Part II.A.

31. Examples of this view are almost too numerous to require citation. See, e.g., Jean Braucher, Contract Versus Contractarianism: The Regulatory Role of Contract Law, 47 Wash. \& Lee L. Rev. 697, 713 (1990); Peter Linzer, Is Consent the Essence of Contract?Replying to Four Critics, 1998 Ann. Surv. Am. L. 213, 217-20 (1988). 
to leave the country, we have consented to obey nearly any command that is enacted by the reigning legal system. And the consent of a majority is supposed to bind not only members of that majority, but dissenters and future generations as well.

The problem of legitimacy considered here is whether the commands of an existing legal system bind the citizenry in conscience. If the issue of legitimacy is only raised when there exists a functioning legal system and there can be no legal system without some for:n of acquiescence, then acquiescence could be viewed as a necessary, but not sufficient, condition of legitimacy. By the same token, if the perception of legitimacy is necessary to obtain acquiescence, then whatever contributes to that perception could also be viewed as a necessary condition of legitimacy.

Nevertheless, incorporating acquiescence into the conception of legitimacy in this way does not affect my basic thesis: To be legitimate in the absence of actual consent, an existing legal system must provide assurances that the laws it imposes are both necessary and proper. ${ }^{32}$ However it is obtained, acquiescence is insufficient to provide this assurance. Though acquiescence may be needed to establish the commands of a legal system as positive law, it is neither the same as, nor an adequate substitute for, actual consent.

\section{The Dangerous Fiction of "We the People"}

Some fictions are harmless, some even beneficial. As Edmund Morgan has shown, the fiction of popular sovereignty originated as an antidote to the fiction of the divine right of the king. ${ }^{33}$ If the king obtained his authority from God, the Commons gained its authority from the People. Paradoxically, the fiction of the divine king was used to limit his power. First, it could be used to deny any intentions to the king that were unworthy of a perfect being. "[D]ivinity, when assumed by mortals (or imposed upon them) can prove more constricting than subjection. Indeed, the attribution of divinity to the king had probably always been motivated in some measure by the desire to limit him to actions becoming a god." 34 Second, the divinity of the king did not extend to anyone but himself, especially excluding the ministers who actually ran afoul of the Commons. "The king was divine and unaccountable, but those he commissioned to act for him shared neither his divinity nor the unaccountability that went with it. To the Commons his agents were all subjects; and if they acted in the king's name, they must do so at their peril." 35

32. 1 borrow this standard from the Constitution itself and will explain below what precisely 1 mean by it. See infra Part II.C. 2.

33. See generally Morgan, supra note 10, at 17-77.

34. Id. at 21.

35. Id. at 33 . 
In a like manner could the fiction of the legislature deriving its just powers from the People be used to constrain its power. True, the "immediate objective of the change in fictions was to magnify the power not of the people themselves, but of the people's representatives." ${ }^{36}$ But a danger immediately emerged: "With the fictional people suddenly supreme, actual people, as embodied in local communities, found their traditional rights and liberties in jeopardy from a representative body that recognized only a fictional superior." ${ }^{37}$ Without some constraint, "the sovereignty of the people would pose graver threats not only to the wishes but also to the rights and liberties of actual people, than the divine right of kings had ever done." 38

The English responses to this threat were varied and took considerable time and struggle to develop. ${ }^{39}$ Later in the United States, after an initial near-disastrous experimentation with legislative supremacy unchecked by a monarchy, the response took the form of constitutional constraints not only on the legislature but on the fictional People themselves. Those who drafted and adopted the Constitution realized better than some of their compatriots what we have largely forgotten: that the reality of rule by legislative majorities combined with the fiction of "We the People" can be a dangerous mixture.

Despite their rhetorical commitment to "popular sovereignty," by the time the Constitution was written, its framers were pretty well convinced that pure majority rule or democracy was a bad idea. As Jack Rakove explains, at the founding it was thought that " $[t]$ he majority deserved not so much to rule as to be protected from misrule, not so much to legislate in pursuit of its interests as to be secured against statutes that would reflect the ambitions of the privileged class." 40

Those who pushed for a new constitution had experienced state governments that were dominated by powerful one-house legislatures, weak governors, and a subservient judiciary-and they did not like what they saw. The result was what Madison called the problem of faction. "By a faction," Madison wrote in Federalist 10, "1 understand a number of citizens, whether amounting to a majority or minority of the whole, who are united and actuated by some common impulse of passion, or of interest, adverse to the rights of other citizens, or to the permanent and aggregate interests of the community." 41

36. Id. at 58 .

37. Id. at 53 .

38. Id. at 82 .

39. See generally id. at 55-121.

40. Jack N. Rakove, Original Meanings: Politics and Ideas in the Making of the Constitution 233 (1997). Rakove's discussion of "the Mirror of Representation" makes clear that the framers of the Constitution were rejecting, or at least mitigating, the competing principle of republican or popular rule that had arisen in the states in the wake of the Revolution. See id. at 203-43.

41. The Federalist No. 10, at 78 (James Madison) (Clinton Rossiter ed., 1961). 
Madison understood, perhaps better than some others of the period, that majorities were as great a danger to the rights retained by the people as a corrupt minority or an individual despot.

Wherever the real power in a Government lies, there is the danger of oppression. In our Governments the real power lies in the majority of the community, and the invasion of private rights is chiefly to be apprehended, not from acts of Government contrary to the sense of its constituents, but from acts in which the Government is the mere instrument of the major number of the Constituents. ${ }^{42}$

By giving power to majorities operating through their representatives, the interest of majorities becomes a greater source of danger both to minorities and to the general welfare under popular government than under other forms.

So great a danger needs to be guarded against carefully. To this end, the founders devised a new scheme in which an electorate of "the People," by voting in elections, would exercise not a lawmaking power, but the power to "check" the lawmakers. "We the People" would not rule directly, but an electorate reflecting the rights and interests of the people would have effective power to check those who would issue commands to the people ${ }^{43}$ By the same token, state governments would have the power to "check" federal legislation through Senators chosen by state legislatures. Their novel and even ingenious scheme of multiple checks and balances was positioned somewhere between rule by a "democratic" majority and rule by an "aristocratic" minority.

In the intervening 200 years, we have moved away from a conception of "popular sovereignty" in which the people, through the electorate, effectively check the exercises of government power, and towards a fiction of "popular sovereignty" in which a democratic majority rules. Many no longer conceive of Congress as an institution charged with performing certain vital tasks, a group of select men and women who are the servants of and checked by the people. Instead they picture Congress as "We the People" itself. Under the prevailing theory of "popular sovereignty," the legislature is thought of as the people personified, entitled to exercise all the powers of a sovereign people.

Some use such slogans as "We are the government" or "the government is us" (though 1 heard this more frequently in my youth before Vietnam and Watergate). This view of government gives legislators an enormous power to do what they will, provided only that they muster the requisite number of votes. For if "we are the government," then we would seem to consent to anything the government does. The fiction of

42. Letter from James Madison to Thomas Jefferson (Oct. 17, 1788), in 1 Letters and Other Writings of James Madison 421, 425 (J.B. Lippincott \& Co. 1867).

43. Notice that while it is a fiction to speak of rule by "the people" as a whole, it need not be at all fictitious to speak of imposing rules on the people or of violating the rights retained by the people. 
popular sovereignty, therefore, becomes dangerous when legislatures are conceived of as a literal surrogate for "We the People" themselves. Because "the people" can "consent" to alienate any particular liberty or right-though not their more abstract inalienable rights-legislatures, as the people's surrogate, can restrict almost any liberty and justify it in the name of popular consent. The fiction of popular rule, as opposed to a popular check on rulers, allows a legislature to justifiably do almost anything it wills. And this, in turn, allows majority and minority factions of the electorate to gain control and wield the power of the legislative branch at the expense of the aggregate rights of their fellow citizens.

\section{Diminishing the Danger: Ackerman's Dualist Democracy}

Bruce Ackerman refers to the view that legislatures function as "the People" themselves as "monistic democracy" in which "[d]emocracy requires the grant of plenary lawmaking authority to the winners of the last general election.... [and] all institutional checks upon the electoral victors are presumptively antidemocratic." ${ }^{44}$ By contrast, Ackerman denies that "the winner of a fair and open election is entitled to rule with the full authority of We the People." 45 Instead, he distinguishes "the will of We the People from the acts of We the Politicians." 46 Ackerman posits a "dualist" constitution in which normal, validly-enacted legislation is not confused with the "higher lawmaking" that "represents the constitutional judgment of We the People." 47 That appellation is limited to lawmaking initiatives that follow an "arduous obstacle course" 48 designed to create a "deepening dialogue between leaders and masses within a democratic structure that finally succeeds in generating broad popular consent for a sharp break with the status quo." 49

Ackerman's dualism represents a refreshing and important improvement over the still-dominant conception of popular sovereignty. To the extent that legislative will is decoupled from "We the People," the danger of that fiction is greatly reduced. No longer is the process of systematically checking legislative rule seen as running afoul of the so-called "countermajoritarian difficulty." 50 Moreover, there is much to be said for dualism as a descriptive account of how constitutional doctrine actually changes over time.

44. Ackerman, Foundations, supra note 13 , at 8 .

45. ld. at 9 .

46. Id. at 10 .

47. Id. at 9 .

48. Id. at 10.

49. Id. at 19. Note the reliance here on "popular consent."

50. See Alexander M. Bickel, The Least Dangerous Branch: The Supreme Court at the Bar of Politics 16-23 (1962) (noting judiciary's role in checking political legislators); see generally Barry Friedman, The History of the Countermajoritarian Difficulty, Part One: The Road to Judicial Supremacy, 73 N.Y.U. L. Rev. 333 (1998) (chronicling challenges to judicial independence). 
Nevertheless, at one juncture Ackerman claims to have provided "a normative argument" 51 that rests on the imperative of gaining the "considered support" of "We the People." 52 This does not mean that he thinks he has provided a normative argument for why individuals are bound to obey constitutional laws. Such a question is neither raised nor addressed in his two works, but the arguments I have offered here suggest that Ackerman's dualist theory of constitutionalism provides no answer.

Though denying the authority of "the People" to ordinary legislation, Ackerman ultimately claims that the result of "higher lawmaking" is entitled to be called the will of "We the People." He speaks freely and unselfconsciously of "principles of higher law validated by the People during their relatively rare success in constitutional politics" 53 and of "fundamental principles ... a affirmed by the People." ${ }^{44}$ But all this too is a fiction and, therefore, could not justify a duty of obedience in the citizenry.

Though "the People" can be said to really exist-pointing to the 250 million or so citizens of the United States, each one of whom also has rights-the people as a whole never speak and never validate anything. Only some subset, whether a majority or minority of the whole, ever vote for or against anything and, even if those who support some constitutional change can somehow bind themselves (which I doubt), their votes cannot bind either dissenters or nonvoters. Consent, as we have seen, does not work that way. Perhaps because he defines his project as largely descriptive (the statement quoted above notwithstanding), Ackerman does not confront the fictional nature of rule by "We the People." This leaves the normative question of constitutional legitimacy-how individuals come to be bound to obey lawful commands-unaddressed by his constitutional dualism.

Recalling Ackerman's vivid account of the transformative effect of "higher lawmaking" leads me to close this Part with an important caveat. I have argued to this point only that a duty to obey the law cannot be grounded on the consent of the governed when there has been anything less than unanimous consent and that, quite obviously, no government legal system can claim this degree of consent. I am not claiming that adoption of constitutions (or laws) by popular vote or conventions is a bad idea. It may well be that such ratification processes are a very good idea because they enhance the likelihood that whatever does legitimate a constitution actually exists. Moreover, such adoption procedures may effectively secure the general acquiescence which is a requirement of any functioning legal order, whether or not it is legitimate.

51. 2 Bruce Ackerman, We the People: Transformations 6 (1998).

52. See id. (describing how dualism "prevents the political elite from undermining the hard-won achievements of the People . . . and mobilize[s] their considered support before foundational principles may be revised in a democratic way").

53. Ackerman, Foundations, supra note 13, at 21.

54. 1d. 
1 am only challenging the widely-held assumption that, because of popular sovereignty or the consent of the governed, "We the People" are even presumptively bound in conscience to obey any law that is enacted by constitutional means. Further, since unanimous consent is never required, in practice the "consent of the governed" is reduced to the consent of a majority of legislators who are elected by a majority of those who vote in an election. "We the People" is, in short, a fiction that, by falsely assuming the presence of consent whenever legislatures enact statutes, has dangerously eroded the rights and liberties of each and every one of the People.

\section{I1. Problematic Alternatives to "We the People"}

In the final analysis, the only way that a duty to obey the law can be based on consent is when consent is given. Anything less than unanimous consent cannot bind those who dissent. Those who acknowledge this take one of two positions. As we saw earlier, some like Raz maintain that there is no prima facie or presumptive duty to obey the law just because it is the law. ${ }^{55}$ Though conceptually defensible, this position is unacceptable in regimes where lawmakers are given the benefit of the doubt and it is widely thought that there exists a duty to obey enacted laws. Others abandon popular sovereignty by contending that lawmaking authority is not based on the "consent of the governed" after all, but on something else. What is this "something else"?

\section{A. Fair Play: Does the Receipt of Benefits Obligate Us to Obey?}

According to one such argument, laws are binding, not because of the consent of "We the People," but because people who receive the benefits of the legal system are bound to obey its demands. It is not consent, they say, but receipt of benefits that binds one. Sometimes called the "principle of fair play," 56 this theory has been much discussed among philosophers and 1 shall not try to summarize the nuances of the debate. ${ }^{57}$

55. See Raz, supra note 8 , at 233.

56. John Rawls's early theory of legal obligation based on the "duty of fair play," while superficially resembling a benefits received argument, actually depends "upon our having accepted and our intention to continue accepting the benefits of a just scheme of cooperation that the constitution defines." John Rawls, Legal Obligation and the Duty of Fair Play, in Law and Philosophy 10 (Sydney Hook ed., 1964) (emphasis added). This therefore is not a pure benefits received argument. "[A]n essential condition of the obligation is the justice of the constitution and the general system of law being roughly in accordance with it. Thus the obligation to obey ... an unjust law depends strongly on there being a just constitution." ld. This makes the structure of Rawls's old theory very similar to that presented in Part Ilt, though it adds a requirement of voluntary acceptance of benefits that $l$ think is unnecessary to justify a prima facie duty to obey laws that are produced by procedures that assure their justice.

57. For a good cross section of scholarly opinion, see generally The Duty to Obey the Law: Selected Philosophical Readings (Williamson A. Edmunson ed., 1999). 
One powerful criticism of this position, by Robert Nozick, is that it too is ultimately based not merely on "receipt" of benefits, but on some notion of consent. ${ }^{58}$ If, out of the blue, I send you a valuable item, are you obliged to pay for it in the absence of consent? Are you even obliged to return it to me? Most would answer no. Likewise, most would believe that we are not obligated to pay for benefits that are thrust upon us by others. Some may say that if you choose to use the item, then you have obligated yourself to pay for it. There may be some merit to this suggestion: Using an item that you know has been sent to you with the expectation of repayment may indicate a consent to pay. (Even this does not necessarily mean, that you are obligated to return the item rather than discard it.) It is still not clear, however, that one is obligated to pay for all unsolicited benefits one receives from others. We may get great pleasure from wonderful architecture, or from seeing an attractive person walk by, without conceding for a moment that we could be charged for the genuine enjoyment we experience.

But I shall not pursue the matter further here, because the kinds of benefits supposedly received from a legal system-the benefit of social cooperation, for example-are benefits that one cannot refuse no matter how hard one tries. Unless one can somehow refuse a benefit that is thrust upon him or her, it is not at all clear that one is obligated to pay for it either in money or in obedience. For the same reason, it is not at all clear why the "benefit" one receives from living in the particular legal system we have-benefits we cannot decline to "enjoy" even if we want to-obligates one to obey the commands of this system.

When we move beyond the benefits of a "scheme of cooperation" supposedly provided by the legal system to tangible benefits-like roads, parks, schools, etc.-we find that most are paid for by taxation, payments that certainly are not consented to in any meaningful way. Must everyone whose income is confiscated to pay for roads, parks, and schools (to some unknowable extent) decline to make use of these resources lest they be accused of voluntarily benefitting from them and, therefore, of owing not only a duty to obey the laws, but a moral duty to pay for them as well?

In an influential essay, John Simmons defends the "fair play" argument against Nozick's critique by denying it is based on mere "receipt" of benefits. A fairer reading, he contends, is that based instead on acceptance of benefits by participants in a particular system.

[F]or an individual to be a real participant in a cooperative scheme, he must have either (I) pledged his support, or tacitly agreed to be governed by the scheme's rules, or (2) played some active role in the scheme after its institution. It is not enough to be associated with the "schemers" in some vague way; one must go out and do things to become a participant or "insider" ... . ${ }^{59}$

58. Robert Nozick, Anarchy, State and Utopia 90-95 (1974).

59. A. John Simmons, The Principle of Fair Play, in The Duty to Obey the Law: Selected Philosophical Readings, supra note 57, at 107, 124-25. 
For Simmons, the problem with the argument so reformulated to avoid collapsing into the tacit consent position, is that "it will by no means be a standard case in which all beneficiaries of a cooperative scheme's workings have accepted the benefits they receive."60

Like unanimous consent, Simmons contends that "benefits accepted" can potentially provide the basis for a duty to obey, but (also like unanimous consent) that its conditions cannot ordinarily be obtained in modern political structures.

While it is clear that at least most citizens of most states receive benefits from the workings of their legal and political institutions, how plausible is it to say that they have voluntarily accepted those benefits, in even the cases of the most democratic political societies now in existence? Not, I think, very plausible. ${ }^{61}$

Simmons describes "acceptance" as an attitude that requires certain attributes.

Among other things, we must understand that the benefits flow from a cooperative scheme, rather than regarding them as "free" for the taking. And we must, for instance, think that the benefits we receive are worth the price we must pay for them (with the burdens involved) or leaving them. ${ }^{62}$

Simmons then denies that most persons have the requisite beliefs and attitudes.

Most citizens will, I think, fall into one of these two classes: those who have not "accepted" because they have not taken the benefits (with accompanying burdens) willingly, and those who have not "accepted" because they do not regard the benefits of government as the product of a cooperative scheme. ${ }^{6.3}$

For all of these reasons, the argument for a duty to obey the laws based on benefits either "received" or "accepted" has fared little better than the argument based on the tacit consent of the governed. But there is more. Someone defending a duty of obedience based on the receipt of benefits might respond that both of these criticisms evade the basic point: Benefits received provide an argument for obedience wholly apart from either consent or acceptance, and for this reason it is inadequate to respond that tacit consent to obey or pay or acceptance of a benefit is lacking.

So let us take this argument at face value and assume that one really does owe a duty of obedience to anyone who takes it upon him or herself, without the consent or acceptance of the recipient, to provide another with (vital?) benefits. Could this not be offered as a justification for the legitimacy of chattel slavery? Could not a slave holder claim, often accurately, that he was indeed providing his charges with vital benefits: food, cloth-

60. Id. at 132 .

61 . Id. at 136 .

62 . Id. at 137 .

63. Id. 
ing, shelter, medical attention when needed, protection from predation by outsiders, and so on? Of course, one might quarrel with the accuracy of this claim, but on what grounds? That food, shelter, and the rest are not "benefits"? Hardly. That these benefits are not adequate? According to what scale of adequacy? Do citizens of severely impoverished countries have no duty to obey the law because the benefits provided by those lawmaking systems are too niggardly? At what point do the benefits become great enough to generate a duty of obedience in the absence of consent? Is the moral problem with chattel slavery that masters do not pay the minimum wage?

To better appreciate why the nonconsensual receipt of benefits cannot be the source of a duty of obedience, imagine a very generous master who provides all essentials and even a degree of choice or freedom to his vassals-or house slaves-which they nevertheless are unable to refuse. Are the slaves of sufficiently bounteous masters morally obligated to obey them? What is the problem with this entire line of argument? The obvious answer is that what is lacking is the consent of the slave. Were there consent to the relationship, then we would not (or should not) describe it as slavery at all-provided that the servant was free to exit the relationship. ${ }^{64}$ But if consent is required to convert a morally impermissible slavery into a duty of obedience, then such consent cannot be fictitious. It must be real, and we already have seen that there is and can be no real consent to the sort of legal system established by the Constitution.

Does all this entail a conclusion that, in the absence of actual consent, the fact that an enacted law is constitutional never gives rise to a duty of obedience? I think not. In Part III, I shall offer an alternative source of the duty to obey laws in the absence of consent. However, at this juncture what is most important is seeing (1) consent to the sort of lawmaking process established by the Constitution is both nonexistent and impossible to achieve; and (2) the dispensation of benefits by lawmakers does not generate a duty to obey their commands in the absence of consent. If such a duty exists, it must be grounded in some other way and, unless some alternative justification exists, there is no duty to obey the commands of these lawmakers.

Though it is not hard to see why consent is needed to convert a slavery relationship to one that is morally permissible, it is sometimes overlooked that this strongly implies the existence of preexisting human

64. Indentured servitude coexisted with chattel slavery throughout most of its history in America. See Abbott Emerson Smith, Colonists in Bondage: White Servitude and Convict Labor in America, 1607-1776, at 336 (1947) ("If we exclude the Puritan migrations of the $1630 \mathrm{~s}$, it is safe to say that not less than one-half, nor more than twothirds of white immigrants to the colonies were indentured servants or redemptioners or convicts."). Such arrangements were voluntary, but still objectionable in my view because the servant was bound to service for a period of years and could not exit. For reasons why this too violates the inalienable rights of persons, see Barnett, Structure of Liberty, supra note 1, at 77-82. Other classical liberals have defended such "voluntary slavery" arrangements as morally permissible. See, e.g., Nozick, supra note 58, at 331. 
rights. For only if persons have a background right to refuse their consent can we ever say they have consented. Such a background right of refusal must, therefore, precede the creation of a duty of obedience based on consent. If consent is the source of a duty to obey the law, then first come rights and only then comes law. As we shall soon see in Part III, in the absence of consent, the preexistence of these background or "natural" rights has important implications for any legal system that claims a duty of obedience.

\section{B. Hypothetical Consent and the Importance of Rights}

Some political theorists rely upon a notion of "hypothetical consent" or that to which a rational person would consent. ${ }^{65}$ To evaluate claims of constitutional legitimacy based on "We the People," we need not get enmeshed in the intricacies of such rational choice theories. It is sufficient to note that hypothetical consent is not actual consent. Indeed, actual consent plays no role in such approaches. Rather, it is a normative approach that is based on a thought experiment about what people under certain conditions ought to consent to, regardless of whether they do consent or not.

In other words, while an argument based on "hypothetical consent" may well provide an argument in favor of certain moral or political principles, such an argument is not based on the real world consent of anyone to anything. This means that hypothetical consent provides no consentbased reason to ignore or evade the background rights of the people-if, that is, people do have rights prior to the formation of a legal system. ${ }^{66}$ Properly understood, arguments based upon hypothetical consent actually help us understand why lawmakers must respect the background rights of the people they purport to bind.

Lysander Spooner was perhaps the earliest American constitutional theorist to recognize that an argument based on hypothetical consent "exist[ing] only in theory" 67 is required to respect the rights of the individ-

65. See, e.g., John Rawls, A Theory of Justice 11 (rev. ed. 1999) ("The choice which rational men would make in this hypothetical situation of equal liberty ... determines the principles of justice.").

66. This is the principal thesis of Barnett, Structure of Liberty, supra note 1. There I argue that certain fundamental rights-as well as the rule of law-are essential to solve the pervasive social problems of knowledge, interest, and power. Though these rights precede the formation of a legal system and are therefore "prepolitical," because they only arise in a social context, they should not be considered "presocial."

67. Lysander Spooner, The Unconstitutionality of Slavery (rev. ed. 1860), reprinted in 4 The Collected Works of Lysander Spooner 1, 153 (Charles Shively ed., 1971) (works in collection separately paginated) [hereinafter Collected Works] ("Our constitutions purport to be established by 'the people,' and, in thenry, 'all the people' consent to such government as the constitutions authorize. But this consent of 'the people' exists only in theory. It has no existence in fact."); see also id. at 225 ("The whole matter of the adoption of the constitution is mainly a matter of assumption and theory, rather than of actual fact."). All of Spooner's writings and letters are readily accessible at http://www. lysanderspooner.org. 
ual because everyone cannot be presumed-in the absence of express or actual consent - to have given up their rights: "Justice is evidently the only principle that everybody can be presumed to agree to, in the formation of government." 68 In the absence of actual consent, a government that protects the rights of all "is the only government which it is practicable to establish by the [theoretical] consent of all the governed; for an unjust government must have victims, and the victims cannot be supposed to give their consent." 69

In sum, an argument based on theoretical or hypothetical consent is inadequate to justify overriding background rights. To the contrary, for a constitution to be legitimate on the basis of hypothetical (as opposed to actual) consent, it must be shown that such a constitution is consistent with the background rights of the individual. In the next Part, I shall consider an alternative conception of constitutional legitimacy that explains both how laws can bind the citizenry in conscience in the absence of consent and why, because consent is lacking, the lawmaking power of government must be limited. 1ndeed, 1 argue that, in the absence of unanimous consent, there is a duty to obey the law only when the legislature's powers are limited.

\section{Constitutional Legitimacy Without Consent}

At some level, advocates of popular sovereignty probably realize full well that there is no real consent to obey the laws made pursuant to the Constitution. Nevertheless, they might contend that, because unanimous consent to a constitution is obviously impossible, majoritarian consent is the closest we can come to real consent and this makes it sufficient to legitimate governance. One response to this argument is that when it comes to consent, coming close is not good enough. Consent is either present or it is absent. Anything short of consent is not consent.

Moreover, if it can be shown that lawmaking based on unanimous consent is both possible and practical, then it could no longer be alleged that majoritarian consent is justified by necessity. With unanimous consent no longer a hopeless ideal, it also becomes easier to see why, in the absence of unanimous consent, legitimacy requires that limits or constraints be imposed on majoritarian governance.

As 1 explain in section III.A, because unanimous consent to governance is possible (though not to the form of governance provided by this Constitution), majoritarian consent cannot be justified on grounds of necessity. Second, as will be discussed in section III.B, the argument contending that majoritarian consent is sufficient as "second best" ignores the constraint that must be imposed on any institution that is legitimated by this type of fictitious consent: The background rights of nonconsenting persons must be protected. Therefore, even if majoritarian rule is necessary, the

68. Id. at 143.

69. Id. 
fact that it lacks actual consent gives rise to an imperative that this form of rule be limited in ways that genuinely consent-based rule need not.

\section{A. More Consent, Less Freedom: Forgoing Rights}

My argument in Part I assumes, uncontroversially, that a duty of obedience could be grounded on consent if everyone consented to be so bound. One reason this condition fails to be met under our constitutional system is that the polity is simply too big ever to consent unanimously to anything. ${ }^{70}$ But suppose that the relevant lawmaking unit was much much smaller than the United States, indeed smaller than any state and even most cities. Would unanimous consent then be possible? 1 think it would. Let me now briefly sketch how unanimous consent is practical.

My parents live in a large private residential community known as Leisure World. When they bought their home, they also expressly agreed to a governance structure that is highly democratic. Leisure World is typical in this regard, though governance arrangements do vary among different residential communities. As with most other communities, the structure of Leisure World empowers the governing board to authorize numerous restrictions on behavior within the community. Houses cannot be expanded without a permit, nor can they be rented for long periods of time. Indeed, no one under fifty-five years of age is allowed to purchase a home in this community.

I could go on at length listing the freedom-constraining regulations that exist in Leisure World. Have my parents consented to obey these rules? Yes, but not in the sense that they consented to each and every rule as it was enacted. Rather, they expressly consented to the existing rules of Leisure World when they purchased their home, and they also expressly agreed to the governance structure by which the rules would be administered and changed. They committed to be bound by the outcome of this structure every bit as much as contracting parties expressly agree to be bound by the outcome of private arbitration when such a clause is in their contract.

In Leisure World, then, there is actual unanimous consent to be bound by the rulemaking process. Why cannot we say the same thing about other lawmaking authorities? One obvious reason is that our consent is never solicited. Would such a solicitation be appropriate? Could the town I live in have required my consent to the outcome of our municipal lawmaking process before it allowed me to reside there? Could the state I live in have required such consent before I moved there? Not without encountering the vicious circle of authority described in Part I. ${ }^{71}$ Unlike the town and state in which I live, Leisure World originally pur-

70. As will be shown shortly, the size of the polity makes unanimous consent impossible only when lawmaking jurisdiction is defined geographically.

71. See supra Part 1.B.2. 
chased and owned all the land on which it is built, and sold parcels only on the condition that purchasers accept its governance structure. Because of its original ownership, it could rightfully condition sale on obedience to the governance structure of Leisure World. ${ }^{72}$

But initial ownership and initial consent are not the only morally relevant differences between communities like Leisure World and polities governed by federal, state, and municipal lawmakers. Leisure World and thousands of communities just like it are also distinguished by the low cost of exit that makes that initial consent meaningful. As Frank Knight emphasized, "effective freedom depends upon an alternative open to the non-conforming individual of leaving the group without suffering loss or damage. In fact, freedom is chiefly a matter of 'competition' between groups for members." 73

Though Leisure World is fairly large-larger than many small towns-it is a relatively small part of a larger metropolitan area. If you do not like the rulemaking system of Leisure World, you can buy a house across the street where the rules and rulemaking procedures may be very different and more to your liking. The cost of exit is quite low.

By "cost of exit" I refer not merely to the financial costs of moving to another location, but to the other sacrifices you make by that choice. ${ }^{74}$ If you want to live and enjoy a particular area, if you do not want to abandon your friends, social network, local customs and cuisine, or job, but you dislike the rules or rulemaking process in Leisure World, you can buy a home across the street, or up the road a bit. This applies when you make your initial decision of where to live as well as when you continue to remain within the jurisdiction. And it applies to nongeographic legal jurisdictions as well.

As I have described elsewhere at greater length, ${ }^{75}$ the jurisdiction of lawmakers over individuals need not be allocated geographically. We can join and consent to the jurisdictions of myriad organizations, each with its own rules and regulations, that stretch around the world and comprise

72. I am not unaware of the serious philosophical issues raised by this paragraph. For example, how do physical resources come justly to be privately owned in the first place, and what conditions can justly be placed on their alienation? While not strictly beyond the scope of this Essay, it would be unduly distracting to parse and pursue them at this point. However they are resolved, the difference remains: Justifying the control over property exercised by persons who obtain title by the consent of previous rightful owners, or by first possession, is a substantially different matter than justifying the claims of some to rule territory belonging to others. This is simply anotber variant of the "first come rights, then comes lawmaking" proposition discussed above. See supra Part II.A; see also infra Part III.B. For further discussion of the rightful acquisition of property, see Barnett, Structure of Liberty, supra note 1, at 69-71, 153-54.

73. Frank H. Knight, Freedom and Reform 416 (1982).

74. See Randy E. Barnett, The Sound of Silence: Default Rules and Contractual Consent, 78 Va. L. Rev. 821, 902-05 (1992) (defending the claim that consent even to immutable contract rules can be actual when the cost of exit is sufficiently low).

75. See Barnett, Structure of Liberty, supra note 1, at 238-97 (describing a "polycentric" constitutional order). 
millions of persons. From employers, to professional associations, to health care organizations, to book clubs, to churches, mosques, and synagogues, to file-sharing networks on the lnternet-the list is endless-each group enjoys the unanimous consent of its members to obey its rules. The cost of exit is low with nongeographically-based jurisdictions precisely because members do not have to leave home to join or to resign their membership. Members can and do actually consent to all sorts of limitations on their freedom. In this way, the exact composition of each person's duty to adhere to the various lawmaking powers of others is likely to be as unique as the individual.

It was Lon Fuller who most famously contended that these sorts of rulemaking activities are as entitled as geographically-based legal systems to be called "systems of law":

If law is considered as "the enterprise of subjecting human conduct to the governance of rules," then this enterprise is being conducted, not on two or three fronts, but on thousands. Engaged in this enterprise are those who draft and administer rules governing the internal affairs of clubs, churches, schools, labor unions, trade associations, agricultural fairs, and a hundred and one other forms of human association.... [T] here are in this country alone "systems of law" numbering in the hundreds of thousands. ${ }^{76}$

What Fuller does not mention is that these myriad legal systems have the moral imprimatur of unanimous consent that large geographically-based legal systems necessarily lack. For when geography defines jurisdiction, size matters.

The larger the land area, the higher the cost of exit and thus the less meaningful is "tacit" consent to the jurisdiction of the lawmaking process. Most modern cities are probably too large, but even if they are small enough, states are certainly too large to command meaningful unanimous consent. If large territorial lawmaking authorities are to command a duty of obedience it must be on some grounds other than the consent of the governed. Of course, when geographically-based lawmaking authorities first purchase the land over which they claim jurisdiction, we can say that consent by subsequent purchasers or lessors to the jurisdiction of the original owner is both consensual and unanimous.

To be clear, simply lowering the cost of exit is no substitute for the initial title by which a rightful owner can condition continued presence on acceptance of a lawmaking procedure. Even with this initial assent, however, were consent-based territories to grow to the size of current jurisdictions, it becomes less clear that consent can be inferred from an unwillingness of persons born therein to incur the cost of exit. To maintain their authority, such consent-based regimes might have to subsidize the exit of those who do not consent. Still, in the real world, the need to

76. See Lon L. Fuller, The Morality of Law 124-25 (rev. ed. 1969). 
raise the funds to make such purchases will naturally limit the size of such jurisdictional claims and keep the cost of exit within reason.

Thus, contrary to conventional wisdom, against a background of initial entitlements, unanimous consent to obey the law is quite possible, but only if the cost of exit is sufficiently small, either because jurisdiction is not geographically based or because the geographical territory is not too large. Where such unanimous consent exists, legal regulations can cover virtually any subject, provided they do not infringe upon inalienable rights or upon the rights of third parties. This is true because persons may consent to alienate or waive many of their rights. The clearest difference between a prize fight and a battery, between making forceful love and rape, is consent.

Under the conditions of unanimous consent, then, liberty is not inconsistent with both heavy regulation and even the prohibition of otherwise rightful conduct. 1ronically, with a governance structure based on unanimous consent, there may be far less freedom of action than in its absence. To the extent that such communitarian constraints on freedom are desirable, this is the context in which they are permissible and binding in conscience.

\section{B. Less Consent, More Freedom: Protecting Rights}

Only when lawmaking authority is imposed over a relatively large geographical area does unanimous consent become impractical. Can such jurisdiction ever be legitimate in the absence of consent and, if so, under what conditions? The answer begins with understanding why, when it does exist, consent legitimates lawmaking.

Consent only legitimates lawmaking on the assumption that "[i]ndividuals have rights, and there are things no person or group may do to them (without violating their rights)."77 Nor is this merely an assumption. As 1 have explained elsewhere, the existence of individual rights is an appropriate conclusion from the nature of human beings and the world in which we live. ${ }^{78}$ This conclusion was accepted by the framers of the United States Constitution as well as by those who wrote the Fourteenth Amendment. ${ }^{79}$

One need not accept any particular formulation of background rights, however, to accept the conception of constitutional legitimacy advanced here. For present purposes, it is only necessary to note that for consent to legitimize a lawmaking process, we must presuppose that consent matters-that people have a right to consent and, by necessary implication, a right to withhold their consent. Otherwise consent would not

77. Nozick, supra note 58 , at ix.

78. See Barnett, Structure of Liberty, supra note 1, at 17-25. 1 do not claim that the argument presented there is the only valid justification for individual rights.

79. I will justify this historical claim in Randy E. Barnett, Restoring the Lost Constitution: The Presumption of Liberty (forthcoming 2003) [hereinafter Barnett, Restoring the Lost Constitution]. 
be required and could not impart legitimacy upon that to which one has consented. In sum, for consent to matter in the first instance, we must assume (and there is also good reason to conclude) that "first come rights, and then comes law" or "first come rights, then comes government." Historically, the rights that people have independently of government were called "inherent" or "natural" rights. Today, they are often referred to as "human" rights.

The assumption that "first come rights, then comes government" helps explain how lawmaking can be legitimate in the absence of consent. For a law would be just, and therefore binding in conscience, if its restrictions on a citizen's freedom were (1) necessary to protect the rights of others, and (2) proper insofar as they did not violate the preexisting rights of the persons on whom they were imposed. The second of these requirements dispenses with the need to obtain the consent of the person on whom a law is imposed. After all, if a law has not violated a person's rights, then that person's consent is simply not required. The first requirement supplies the element of obligation. If a law is necessary to protect the rights of others, then it is as obligatory for the person on whom it is imposed as protecting that person's rights are obligatory on the legal system itself. ${ }^{80}$ Persons have an obligation to obey such a law just as they have an obligation to respect the rights of others.

We have then reached an ironic conclusion: With unanimous consent, there can be many more legitimate restrictions on freedom than when consent is absent. Because people may consent to just about anything, they have the liberty to consent to laws that greatly restrict their frecdom. However, in the absence of actual consent, their background liberty rights remain intact and must not be infringed. In sum, while actual consent can justify restrictions on freedom, without actual consent, liberty must be strictly protected. Therefore, when we move outside a community constituted by unanimous consent, laws must be scrutinized to ensure both that they are necessary and that they do not improperly infringe upon the rights retained by the people.

\section{Clarifications and Caveats}

This theory of constitutional legitimacy is susceptible to being misunderstood in several ways. To avoid this, I should emphasize precisely what I am claiming and the limits of this claim.

1. Beyond Respecting and Protecting Rights. - In this Part, I am only offering a justification for a duty of obedience in the absence of consent, a justification that extends only to laws that are both necessary to protect the rights of others and proper insofar as they do not violate the rights of the persons whose freedom they restrict. I do not claim that my argu-

80. This is true as well when government is regulating or restricting the use of its own property. In such cases, the rights it is protecting are its own, though it might be wise to put restrictions on how government may use or restrict the use of its own property. 
ment on behalf of this limited duty of obedience also provides an affirmative argument against any other source of nonconsensual legitimacy that might broaden a moral duty of obedience.

Though my argument does not itself rule out other potential justifications of nonconsensual duties of obedience, those who claim that a person's freedom may be restricted for ends other than the protection of rights must justify this further extension of power. 1n Part 1, we saw the weakness of arguments based on tacit consent and benefits received. Elsewhere 1 have explored the surprising weaknesses of arguments based on retributive and distributive justice. ${ }^{81}$

Though the strength of procedural protections that both respect and protect background rights justifies a duty of nonconsenting persons to obey the law, this particular rationale extends only so far and no farther. Readers who want more than this from lawmaking might want to consider the protection of background rights a baseline by which to assess legitimacy. That is, a legitimate legal system is one that provides assurances that its liberty-restricting commands are necessary to protect the rights of others and do not improperly violate the rights of those on whom they are imposed. Whether a legal system that does more (or less) than this is also legitimate is an open question that requires additional analysis and justification.

1t also bears mentioning that a large proportion of government action does not involve coercively imposing commands on the citizens. When the Post Office sets its hours of operation or the price of its postage stamps it is acting in the capacity of an owner of a business. $1 \mathrm{t}$ is no more restricting the rightful freedoms of the citizenry than a private organization that does the same. Such commands are perfectly proper under Article 1, Section 8 which gives Congress the power "to establish Post Offices." ${ }^{82}$ However, when Congress claims for its post office a monopoly and punishes those who would carry mail in competition with it-a power nowhere enumerated in the Constitution ${ }^{83}$-it would have the burden of showing the necessity and propriety of such a command or it would not be binding in conscience.

Even without additional justification, however, the theory of constitutional legitimacy advanced here does not rule out more ambitious impositions of duties on persons than the protection of rights. On this account, there are two, not one, sources of binding law: laws that are produced by unanimous consent regimes, and laws that are produced by regimes whose legitimacy rests solely on procedural assurances that the rights of the nonconsenting persons on whom they are imposed have been protected. Whatever additional types of laws and regulations beyond the protection of rights are thought desirable can usually be obtained within

81. See Barnett, Structure of Liberty, supra note 1 , at 308-21.

82. U.S. Const. art. I, $\$ 8$.

83. See Lysander Spooner, The Unconstitutionality of the Laws of Congress, Prohibiting Private Mails (1844), reprinted in 1 Collected Works, supra note 67, at 1, 5 . 
the unanimous consent communities that, as we have seen, are both possible and pervasive.

Like Leisure World, academic and religious communities, for example, impose a wide variety of additional duties on their members. Those who insist that geographical nonconsent-based lawmaking is necessary because unanimous consent to lawmaking is impossible are simply in error. That which already exists is clearly possible. And those who contend that these unanimous consent communities are somehow inadequate must justify, not merely assert, their claim. In so doing, they must be careful to show why the same deficiencies do not apply as well to nonconsensual territorially-based legal systems-especially in a world in which a diversity of such systems compete with one another and no one legal system can ensure the right outcome in all the others.

Still, depending on the view of rights we adopt, even unanimous consent regimes may be subject to some limit to the duties they can legitimately impose. If there are some rights that cannot be waived or transferred, even by the consent of the right holder, then unanimous consent regimes, to be legitimate, must offer procedural assurances that these inalienable rights have been protected. Inalienable rights are those that can be reclaimed, even after they are waived by a right holder. ${ }^{84}$ For example, while one can consent to fight in a ring or to have sexual relations with another person, the inalienable nature of the right to one's own person entails that one can always change one's mind and refuse to continue. On this account of inalienable rights, the most important procedural feature that even unanimous consent regimes must respect would be the preservation of a perpetual right to exit the regime. ${ }^{85}$

This last point also highlights the relationship between the theory of legitimacy defended here and the theory of justice upon which the legitimacy of any particular legal system depends. Such a right of exit is not a feature of the concept of constitutional legitimacy defended here. Rather it is a procedure that would protect against the violation of certain inalienable rights. Though one can accept the procedural conception of legitimacy advanced here without concurring on a particular theory of justice, determining which procedures are needed to ensure that laws promulgated by a particular legal system are not unjust will depend on the conception of justice one holds.

2. The Meaning of "Necessary $\mathcal{F}^{2}$ Proper." - I have borrowed the standard of "necessary and proper" from the Constitution itself. Article I grants Congress the power to "make all Laws which shall be necessary and proper for carrying into Execution" 86 the other powers that are vested by the Constitution in the national government. I am not claiming that the original meaning of this clause is identical to the meaning I contend is

84. See generally Terrance C. McConnell, Inalienable Rights 3-44 (2000).

85. I thank Dawn Nunziato for her insightful comments that led to this caveat on the legitimacy of unanimous consent regimes.

86. U.S. Const. art. I, $\S 8$. 
the prerequisite of constitutional legitimacy. ${ }^{87}$ Two differences are immediately apparent.

The Necessary and Proper Clause requires that laws be necessary to the execution of any power delegated to the national government by the Constitution, not just the power to protect the rights of others. In this respect, the clause has a conception of "proper" that is broader or more permissive than mine. Part of the reason for this is that the government is charged with performing many functions, the performance of which does not require the restriction of personal freedom. On the other hand, as has been shown by Gary Lawson and Patricia Granger, propriety includes not only the protection of individual rights but also an adherence to principles of federalism and separation of powers. ${ }^{88}$ In this respect, the clause is narrower or less permissive. A law that violates principles of federalism may be improper even though it does not infringe upon the rights of individuals.

In the absence of actual consent, then, every freedom-restricting law must be scrutinized to see if it is both necessary to protect the rights of others and does not improperly violate the rights of those whose freedom is restricted. In the absence of actual consent, a legitimate lawmaking process is one that provides adequate assurances that the laws it validates are just in this respect. If a lawmaking process provides these assurances, then it is legitimate and the commands it issues are entitled to a benefit of the doubt. They are binding in conscience unless shown to be unjust.

\section{ConCLusion}

The problem of constitutional legitimacy is to establish why, in the absence of actual consent to be bound, anyone should care what a constitutionally valid law may command. I am not asking why people perceive a constitution to be legitimate and constitutional laws binding in con-

87. I discuss the original meaning of this clause at length in Randy E. Barnett, Necessary and Proper, 44 UCLA L. Rev. 745, 751-63 (1997) (distinguishing between Madisonian and Marshallian conceptions of "necessity"). In Restoring the Lost Constitution, I qualify somewhat my historical claims by showing how Madison's (and others') conception of "necessity" was closer-though by no means identical-to that of Hamilton (and Marshall) than is commonly believed. See Barnett, Restoring the Lost Constitution, supra note 79; see also David P. Currie, The Constitution in the Supreme Court: State and Congressional Powers, 1801-1835, 49 U. Chi. L. Rev. 887, 932 (1982) (discussing John Marshall's opinion in McCulloch v. Maryland and concluding that “[i]n light of earlier statements in his opinion, the implication seems unmistakable: incidental authority must not be so broadly construed as to subvert the basic principle that Congress has limited powers").

88. Gary Lawson \& Patricia B. Granger, The "Proper" Scope of Federal Power: A Jurisdictional Interpretation of the Sweeping Clause, 43 Duke L.J. 267, 297 (1993) (arguing that to be proper, "executory laws must be consistent with principles of separation of powers, principles of federalism, and individual rights"); see also Printz v. United States, 521 U.S. 898, 923-24 (1997) ("When a 'La[w] . . . for carrying into Execution' the Commerce Clause violates the principle of state sovereignty . . . it is not a 'La[w] . . proper for carrying into Execution the Commerce Clause.'"). 
science. Instead, I am asking what qualities a constitution should have to justify this perception. My answer is that we may owe a prima facie duty to obey a constitutionally valid law only if the constitutional processes used to enact laws provide good reasons to think that a law restricting freedom is necessary to protect the rights of others without improperly infringing the rights of those whose liberty is being restricted.

As we have already seen, this quality depends upon the presence or absence of consent. When consent is present, a lawful command can restrict almost any freedom except an inalienable right. However, when consent is lacking, as it is with respect to the Constitution of the United States, to bind in conscience, a law must be both necessary to the protection of the rights of others and proper insofar as it does not violate the rights of those upon whom it is imposed. A constitutionally legitimate lawmaking process provides an assurance that both these requirements have been met.

What exactly are these rights that a legitimate lawmaking process must assure us have not been violated? I myself maintain that the natural rights people have before they form a legal system and which they retain unless they consent to their alienation are "liberty rights." 89 I further maintain that, as a matter of positive law, the Ninth Amendment affords protection to these liberty rights "retained by the people" from the national government, while the Privileges or Immunities Clause of the Fourteenth Amendment protects the same liberty rights (and others) from violation by states. ${ }^{90}$ Moreover, if protecting background rights is the only thing that justifies imposing legal commands on nonconsenting people, the more expansive is one's conception of rights, the greater the number of commands one will believe are warranted. For this reason, recognizing the absence of consent seems to argue for a less ambitious, rather than a broader, conception of background rights.

You do not, however, have to agree with the framers' or with my account of justice or natural rights to accept the theory of constitutional legitimacy advanced in this Essay. We can be in full agreement that, when consent is lacking, a constitution is legitimate only when it provides sufficient procedures to assure that the laws enacted pursuant to its procedures are just. ${ }^{91}$ At the same time, we can disagree about what it is that makes a law just and, for that matter, what procedures are sufficient to

89. This normative claim is the principal thesis of Barnett, Structure of Liberty, supra note 1.

90. U.S. Const. amends. IX, XIV. This descriptive historical claim is defended at length in Barnett, Restoring the Lost Constitution, supra note 79.

91. This argument is actually quite similar in structure to that of Rawls:

[1] $\mathrm{n}$ the constitutional convention the aim of the parties is to find among the just constitutions ... the one most likely to lead to just and effective legistation in view of the general facts about the society in question. The constitution is regarded as a just but imperfect procedure framed as far as the circumstances permit to insure a just outcone.

Rawls, supra note 65 , at 353 . 
assure that laws are likely to be just in the relevant sense. This is no different than theorists who agree that the "consent of the governed" legitimates a constitution while disagreeing about what constitutes such consent and whether it exists in a particular case.

My claim here is only that (1) anything short of actual consent cannot bind a nonconsenting party; (2) the U.S. Constitution is legitimated neither by actual consent of the governed nor by receipt of benefits; (3) unanimous consent to lawmaking is both possible and pervasive; but (4) in the absence of actual unanimous consent, to be legitimate, a constitution must provide sufficient procedural assurances that whatever quality makes a law just and therefore binding in conscience goes in before the name law goes on a particular command. ${ }^{92}$

For better or worse, this makes legitimacy outside of unanimous consent legal regimes a matter of degree rather than an all-or-nothing characteristic. Above the threshold where a law is more likely than not to be just, the more effectively procedures ensure that valid laws are just, the greater the presumption to be accorded those laws enacted under them. The more confidence we have in enacted laws, the more skeptical we can be about a claim that a particular law is unjust. In this Essay, it is not possible for me to describe all the characteristics that I believe contribute to legitimate lawmaking. Familiar features of our legal system-widespread suffrage, separation of powers, federalism, and a written constitution that "locks in" these practices as well as lists both enumerated powers and enumerated rights-each play a role if properly respected. So too does judicial review by ensuring that these legitimacy-enhancing features are indeed respected. So too would the adoption of a "presumption of liberty," which would place the burden on the government to justify to a court that its freedom-restricting commands are both necessary and proper. ${ }^{93}$

By acknowledging that, above a certain threshold, constitutional legitimacy is a matter of degree, the theory I am proposing does not always provide a clean answer to the question of whether a particular lawmaking process, taken as a whole, is sufficient to provide enacted legislation with the benefit of the doubt. But it does confront the question that others

92. Elsewhere, I make the further claim that, if a particular legal system includes the adoption of a written constitution to "lock in" the other procedural features that help ensure laws are just, then within such a system, judges, when interpreting the text, must adhere to the original meaning of the written constitution to the extent that this meaning can be ascertained. Randy E. Barnett, An Originalism for Nonoriginalists, 45 Loy. L. Rev. 611,643 (1999). Where that meaning is vague or incomplete, however, supplementation or "construction" is permissible-indeed inevitable-and constitutional constructions that do not contradict original meaning should be adopted when they enhance whatever it is that makes laws legitimate. 1d. at 645-47. I greatly expand upon this discussion in Barnett, Restoring the Lost Constitution, supra note 79.

93. I offer a preliminary defense of the "presumption of liberty" in Barnett, Getting Normative, supra note 8, at 113-21, and an extended defense in Barnett, Restoring the Lost Constitution, supra note 79. 
neglect and answers it by positing something real, not fictitious, that we should be looking for: procedures that assure that enacted legislation does not violate the rights retained by the people. And it also allows us to conclude that some constitutions are more legitimate than others.

$1 \mathrm{t}$ is an open question whether the U.S. Constitution-either as written or as actually applied-is in fact legitimate. Intellectual honesty requires us to acknowledge the possibility that no constitution lacking unanimous consent is capable of producing laws that bind in conscience. Therefore, though the conception of legitimacy offered here may not always be easy to apply, and though it invites debate and controversy about the nature of justice and rights, even skeptical readers might want to give it the benefit of the doubt. For their alternative may be to admit that there is no one behind the curtain. 